\title{
Immunostaining, Dehydration, and Clearing of Mouse Embryos for Ultramicroscopy
}

\author{
Klaus Becker, Nina Jährling, Saiedeh Saghafi, and Hans-Ulrich Dodt
}

\begin{abstract}
This protocol describes the preparation of mouse embryos for ultramicroscopy (UM), a powerful imaging technique that achieves precise and accurate three-dimensional (3D) reconstructions of intact macroscopic specimens with micrometer resolution. In UM, a specimen in the size range of $\sim 1-$ $15 \mathrm{~mm}$ is illuminated perpendicular to the observation pathway by two thin counterpropagating sheets of laser light. In combination with fluorescein isothiocyanate (FITC) immunostaining, UM allows visualization of somatic motor and sensorial nerve fibers in whole mouse embryos. Even the fine branches of the sensomotoric fibers can be visualized over a distance of up to several millimeters. In this protocol, mouse embryos are fixed and immunostained in preparation for UM. Because UM requires the excitation light sheet to travel throughout the entire horizontal width of the specimen, specimens usually have to be rendered transparent before microscope inspection. Here, the embryos are dehydrated in ethanol and then cleared in a solution of benzyl alcohol and benzyl benzoate.
\end{abstract}

\section{MATERIALS}

It is essential that you consult the appropriate Material Safety Data Sheets and your institution's Environmental Health and Safety Office for proper handling of equipment and hazardous materials used in this protocol.

RECIPE: Please see the end of this article for recipes indicated by $<R>$. Additional recipes can be found online at http://cshprotocols.cshlp.org/site/recipes.

Reagents

BABB clearing solution (two parts benzyl benzoate and one part benzyl alcohol) Blocking serum (four parts calf serum and one part dimethylsulfoxide [DMSO]) DENT's fix (one part DMSO and four parts methanol; Dent et al. 1992)

Ethanol (50\%, 70\%, 80\%, 96\%, and 100\% for dehydration series)

Hydrogen peroxide $\left(\mathrm{H}_{2} \mathrm{O}_{2} ; 30 \%\right)$

Primary antibody (e.g., monoclonal anti-neurofilament 160 clone NN18, Sigma-Aldrich)

Secondary antibody (e.g., goat anti-mouse conjugated to Alexa488, Invitrogen)

TBS (10×) for mouse embryos $<\mathrm{R}>$

Equipment

Vials

Adapted from Imaging: A Laboratory Manual (ed. Yuste). CSHL Press, Cold Spring Harbor, NY, USA, 2010.

(C) 2013 Cold Spring Harbor Laboratory Press

Cite this article as Cold Spring Harb Protoc; 2013; doi:10.1101/pdb.prot076521 
K. Becker et al.

\section{METHOD}

\section{Fixation and Immunostaining}

1. Fix embryos overnight in DENT's fix.

2. Bleach the embryos overnight in one part $30 \% \mathrm{H}_{2} \mathrm{O}_{2}$ and two parts DENT's fix.

3. Wash the embryos three times in TBS for $30 \mathrm{~min}$.

4. Incubate them for $2 \mathrm{~d}$ at room temperature in the primary antibody solution (e.g., monoclonal anti-neurofilament 160 clone NN18 diluted 1:200 in blocking serum).

5. Wash the embryos three times for $1 \mathrm{~h}$ in TBS.

6. Incubate them for $2 \mathrm{~d}$ at room temperature in the secondary antibody solution (e.g., goat antimouse conjugated to Alexa488 diluted 1:200 in blocking serum).

7. Wash the embryos at least five times in TBS (1 h each).

Dehydration and Clearing

Perform the steps at room temperature. Slowly agitate the vials containing the specimens during each incubation step.

8. Dehydrate immunostained and fixed embryos in an ascending ethanol series (E12.5 embryos: $50 \%, 70 \%, 80 \%, 96 \%, 3 \times 100 \%, 1$ h each, last step overnight). For older embryos, the incubation times may have to be prolonged.

9. Transfer the embryos into BABB and incubate them for at least $2 \mathrm{~d}$.

RELATED INFORMATION

See Becker et al. (2008) and Ultramicroscopy: Light-Sheet-Based Microscopy for Imaging Centimeter-Sized Objects with Micrometer Resolution (Becker et al. 2013).

TBS (10×) for Mouse Embryos

\begin{tabular}{lc} 
Reagent & Amount to add \\
\hline $\mathrm{NaCl}$ & $87.7 \mathrm{~g}$ \\
Tris-Cl $(1 \mathrm{M}, \mathrm{pH} 8.0)$ & $100 \mathrm{~mL}$ \\
$\mathrm{H}_{2} \mathrm{O}$ & to $1 \mathrm{~L}$
\end{tabular}

Dilute to $1 \times$ before use.

\section{REFERENCES}

Becker K, Jährling N, Kramer ER, Schnorrer F, Dodt H-U. 2008. Ultramicroscopy: 3D-reconstruction of large microscopic specimens. J Biophotonics 1: 36-42.

Becker K, Jährling N, Saghafi S, Dodt H-U. 2013. Ultramicroscopy: Lightsheet-based microscopy for imaging centimeter-sized objects with micrometer resolution. Cold Spring Harb Protoc doi: 10.1101/pdb. top076539.

Dent JA, Cary RB, Bachant JB, Domingo A, Klymkowski MW. 1992. Host cell factors controlling vimentin organization in the Xenopus oocyte. J Cell Biol 119: 855-866. 


\section{Immunostaining, Dehydration, and Clearing of Mouse Embryos for Ultramicroscopy}

Klaus Becker, Nina Jährling, Saiedeh Saghafi and Hans-Ulrich Dodt

Cold Spring Harb Protoc; doi: 10.1101/pdb.prot076521

\begin{tabular}{rc}
$\begin{array}{r}\text { Email Alerting } \\
\text { Service }\end{array}$ & Receive free email alerts when new articles cite this article - click here. \\
\hline $\begin{array}{c}\text { Subject } \\
\text { Categories }\end{array}$ & $\begin{array}{c}\text { Browse articles on similar topics from Cold Spring Harbor Protocols. } \\
\text { Immunostaining (139 articles) } \\
\text { Light Microscopy (61 articles) } \\
\text { Mouse (437 articles) }\end{array}$ \\
\hline
\end{tabular}

